\title{
Physiological maturity of seeds and colorimetry of the fruits of Allophylus edulis [(A. St.-Hil., A. Juss. \& Cambess.) Hieron. ex Niederl.. ${ }^{1}$
}

\author{
Daiana Karoline Kaiser ${ }^{2 *}$, Marlene de Matos Malavasi ${ }^{2}$, Ubirajara Contro \\ Malavasi², João Alexandre Lopes Dranski ${ }^{2}$, Laura Cristiane Nascimento de \\ Freitas $^{2}$, Carla Rosane Kosmann ${ }^{2}$, Katia Kabroski Andrioli ${ }^{2}$
}

\begin{abstract}
This study aimed to determine the physiological maturity of $A$. edulis seeds, check if this is achieved in the same maturation stage, regardless of the collection region and, colorimetry of the fruit can be indicative of the time of harvest. Fruits were harvested in three counties of the western region of Paraná and visually classified into five ripening stages according to the color of the pericarp with the help of a digital colorimeter. Analyzed seed variables included morphological characteristics, germination and vigor. The experiment was conducted in a completely randomized design with four replications. The maximum dry matter accumulation of seeds was reached when the fruits reached the color orange. With the advance of the ripening process, red color fruits had seeds with lesser moisture content, coinciding with the maximum germination percentage and speed, besides generating seedlings with larger size and biomass accumulation. The green spectrum allowed to discriminate maturity from different places of harvest. A. edulis seeds with physiological maturity should be harvested when fruits present the red color, independent of the harvesting region or, with reflectance values between 28.0 and $49.2 \mathrm{~nm}$ in the green range of the color spectrum.
\end{abstract}

Index terms: vacum, harvesting season, ripening, color analyzer.

\section{Maturidade fisiológica de sementes e colorimetria dos frutos de Allophylus edulis [(A. St.-Hil., A. Juss. \& Cambess.) Hieron. ex Niederl.]}

\begin{abstract}
RESUMO - Objetivou-se determinar a maturidade fisiológica de sementes de A. edulis, verificar se esta é alcançada no mesmo estádio de maturação do fruto, independentemente da região de coleta e, se a colorimetria do fruto poder ser indicativa do momento de colheita. Frutos colhidos em três municípios da região do Oeste do Paraná foram classificados visualmente em cinco estádios de maturação de acordo com a coloração do epicarpo e com o auxílio de um colorímetro digital. As variáveis analisadas nas sementes compreenderam características morfológicas, germinação e vigor. O experimento foi conduzido em delineamento inteiramente casualizado, com quatro repetições. O máximo acúmulo de matéria seca das sementes foi alcançado quando os frutos possuíram coloração laranja. Com o avanço da maturação, frutos com coloração vermelha possuíram sementes com menor grau de umidade, coincidindo com a máxima porcentagem e velocidade de germinação, além de gerarem plântulas com maior tamanho e acúmulo de biomassa. $\mathrm{O}$ espectro verde permitiu discriminar a maturidade nos diferentes locais de colheita. Sementes de $A$. edulis com maturidade fisiológica devem ser colhidas quando os frutos estiverem com coloração vermelha, independentemente da região de colheita ou, com valores de reflectância entre 28,0 a 49,2 nm na escala verde do espectro de cores.
\end{abstract}

Termos para indexação: vacum, época de colheita, maturação, analisador de cor.

\section{Introduction}

The Sapindaceae family consists of 141 genera and 1,900 species (Acevedo-Rodríguez et al., 2011), of which 28 genera and 418 species occur in Brazil. Of these, 12 genera and 65 species occur in the Brazilian state of Paraná
(Somner et al., 2015). Allophylus edulis, popularly known as vacum (among several other names), is among the species of this family that have a broad geographic distribution and great importance in Mixed Ombrophilous (Cordeiro and Rodrigues, 2007) and Seasonal Semidecidual forests in the state of Paraná (Gris et al., 2012). The species has

\footnotetext{
${ }^{1}$ Submitted on 9/19/2015. Accepted for publication on 4/15/2016.

${ }^{2}$ Centro de Ciências Agrárias, Universidade Estadual do Oeste do Paraná, Caixa Postal 91, 85960-000 - Marechal Cândido Rondon, PR, Brasil.

*Corresponding author < daianakaiser@hotmail.com>
} 
an importance value ranging from $3.09 \%$ in the Deciduous Seasonal forest to $5.55 \%$ in the Mixed Ombrophilous forest (Hack et al., 2005; Cordeiro and Rodrigues, 2007) which justifies the use of its seeds for environmental recovery purposes of these vegetation formations.

Sexual propagation is the most used method for the production of seedlings of forest species, which makes harvesting and the use of seeds with quality essential for the success of this activity, as seeds with high levels of vigor and germination are required for the production of seedlings with superior quality (Savva et al., 2010). Some studies significantly contribute to the description of A. edulis seed physiology (Abreu et al., 2005; José et al., 2007). However, knowledge of ripening and the right time for seed harvest of this species have not yet been fully established.

Ripening is the result of a series of morphological, biochemical and physiological changes directly influenced by genetic and environmental factors that occur from fertilization to the independence of the seeds with the parent plant. These changes include a set of preparatory steps for the germination process, characterized essentially by the synthesis and accumulation of reserves (Marcos-Filho, 2015).

For the harvesting of forest seeds, physical parameters are generally adopted, such as changing the color of fruits and seeds, size, odor, presence of predators, dispersers and dehiscence of fruit as indicators of ripening (Piña-Rodrigues and Aguiar, 1993). Among these characteristics, changes of fruit color has been the most widely used indicator, since many fruit species change their color as they ripe (Dranski et al., 2010; Herzog et al., 2012; Oro et al., 2012; Srimathi et al., 2013; Lopes et al., 2014).

Human identification of colors is obtained from a complex sensation of brightness, intensity and clarity. However, in the perception of the primary colors and their shades, color definition assumes abstractness (Lima et al., 2007) allowing different interpretations for the same color. Added to this, fruits of the same species may show variation in color of the epicarp depending on the region of origin (Duarte et al., 2012; Cordeiro et al., 2013) which requires the use of better techniques to evaluate these variations safely.

The identification of fruit color by using a color measurement instrument as a digital colorimeter can provide a more reliable evaluation of fruit ripening stages from different harvesting regions, providing that physiologically ripe seeds can be obtained with greater quality for the production of seedlings.

The objectives of this study were: (1) to determine physiological maturity of seeds of A. edulis; (2) to check if the maturity is achieved in the same fruit ripening stage regardless of the harvesting region; (3) to verify if the colorimetry of the fruit can be used to indicate the time of harvest.

\section{Material and Methods}

Seeds of A. edulis were obtained from fruits randomly harvested in September 2014 from three adult trees at each site, in the Brazilian municipalities of Santa Helena (24'56'22"S, $54^{\circ} 20^{\prime} 31^{\prime \prime} \mathrm{O}$, altitude $263 \mathrm{~m}$ ), Entre Rios do Oeste (2440'22"S, $54^{\circ} 16^{\prime} 51^{\prime \prime} \mathrm{O}$, altitude $241 \mathrm{~m}$ ) and Guaíra (240. $04^{\prime} 39^{\prime \prime} \mathrm{S}, 54^{\circ} 15^{\prime} 43^{\prime \prime} \mathrm{O}$, altitude $234 \mathrm{~m}$ ), in western Paraná, Brazil. Climatic conditions for the three sites were monitored from flowering to harvest of the fruits (Figure 1). Having the data of relative humidity and air temperature, vapor pressure deficit was calculated according to the methodology proposed by Landsberg and Sands (2011).

Fruits harvested directly from the trees were visually classified into five ripening stages based on epicarp color: green fruits; fruits in the transition from green to yellow; yellow fruits; orange-colored fruits and red fruits (Table 1). After visual classification, the color of the epicarp was described based on "Munsell color charts for plant tissues" (Munsell, 1976) (Table 1) and subsequently quantified by the reflectance ratio of the color spectrum red, green and blue using a digital color analyzer model ACR-1023 (Instrutherm ${ }^{\circledR}$ ). The reflection ratio values $(\mathrm{nm})$ were measured from 300 fruits, uniformly distributed over two petri dishes $(100 \times 15 \mathrm{~mm})$, and five readings were taken per plate. After the five readings, the samples were mixed and the same procedure was repeated, totaling 20 readings per ripening stage and harvesting region.

Subsequently, the seeds were manually extracted from the fruits and then the moisture content, in percentage, was determined by the drying method in an oven at $105 \pm 3{ }^{\circ} \mathrm{C}$ during $24 \mathrm{~h}$ (Brasil, 2009) in four replications of 25 seeds, also quantifying the dry matter mass of the seeds (mg per seed).

The seeds biometrics evaluation ( $\mathrm{mm}$ per seed) consisted of measuring length (measured in the region perpendicular to the micropyle) and diameter (measured in the median area adjacent to the micropyle) from four replications of 25 seeds, using a digital caliper.

The germination test was conducted with four replications of 50 seeds per ripening stage and harvesting region, sown on germitest ${ }^{\circledR}$ paper roll moistened with distilled water, the volume of which was the one that made it possible to reach 2.5 times the mass of the paper. Then the rolls were placed in a B.O.D. (Biochemical Oxygen Demand)-type germination chamber at $25.0 \pm 2.0^{\circ} \mathrm{C}$, with a photoperiod of $12 \mathrm{~h}$ (Abreu et al., 2005). The results were expressed as percentage of normal seedlings obtained after 52 days after sowing, at which time there was no additional germination. During the germination test, daily counts of normal seedlings were made to obtain the germination speed index (GSI), as proposed by Maguire (1962) and the mean germination time (MGT) proposed by Laboriau (1983). 

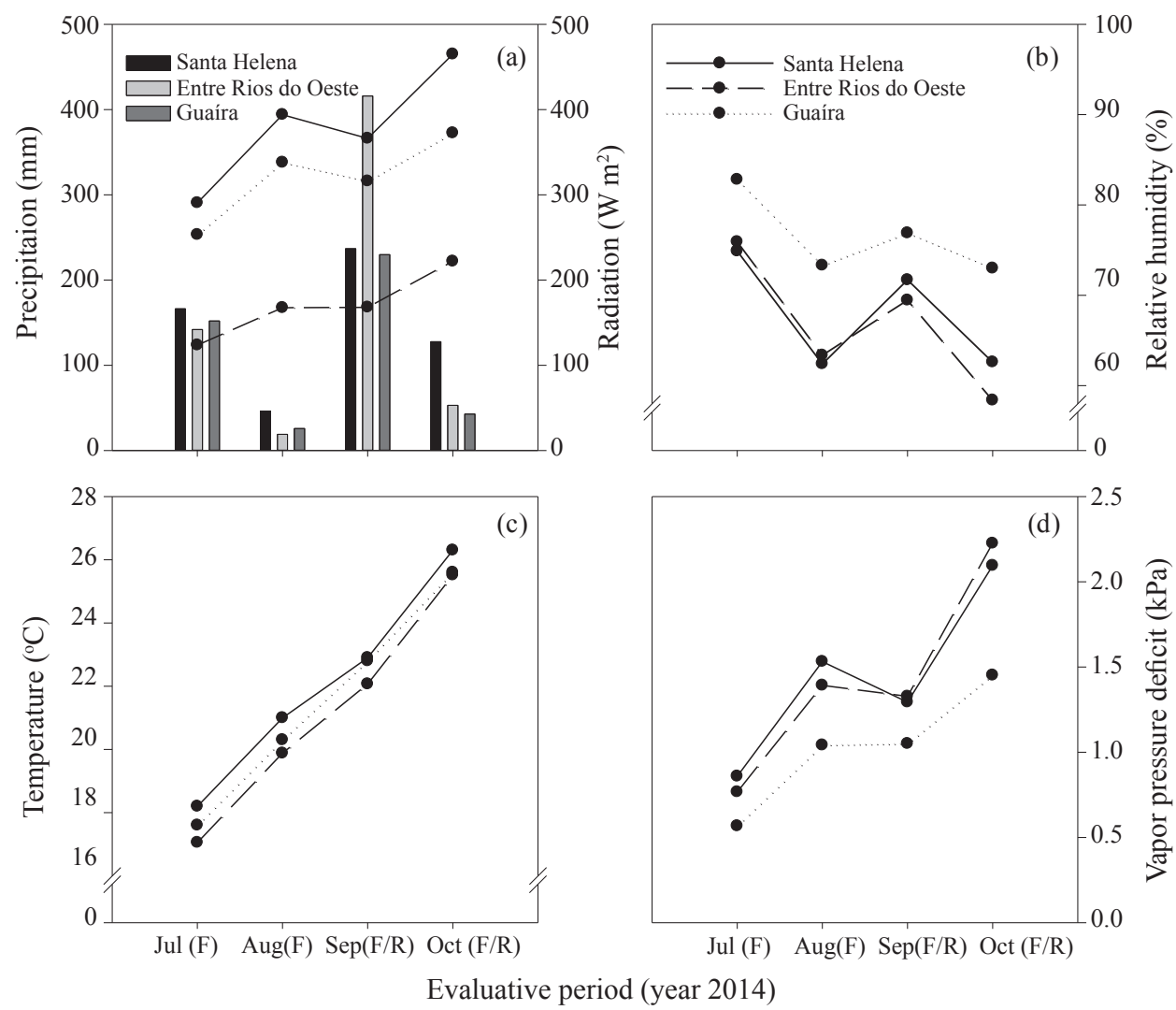

Figure 1. Accumulated precipitation and average solar radiation (a), monthly average relative humidity (b), of temperature (c) and vapor pressure deficit (d) during the flowering (F) and ripening (R) periods of the fruits of A. edulis in the Brazilian municipalities of Santa Helena, Entre Rios do Oeste and Guaíra, PR. Source: SIMEPAR (2014). For Entre Rios do Oeste, weather data from the weather station nearest to the seeds harvesting site were used $(\approx 30 \mathrm{~km})$.

Table 1. Coloring of fruits of A. edulis in different ripening stages, harvested in the municipalities of Santa Helena (1), Entre Rios do Oeste (2) and Guaíra (3), Paraná, Brazil, 2014.

\begin{tabular}{llcc}
\hline $\begin{array}{c}\text { Stage of ripening } \\
\text { of the fruit }\end{array}$ & \multicolumn{2}{c}{ Munsell's chart } \\
\hline \\
Green-yellow \\
Yrange
\end{tabular}

Horizontal bars: $6.20 \mathrm{~mm}$. 
At the end of the germination test, the length of the normal seedlings ( $\mathrm{cm}$ per seedling) was measured from the lower end of the main root to the apical meristem. Seedlings were dried in an air circulation oven at $80^{\circ} \mathrm{C}$ for $24 \mathrm{~h}$ (ISTA, 1995) and their dry matter (mg per seedling) was determined according to Nakagawa (1999).

The experiment followed a completely randomized design, comprising five ripening stages with four replications. Harvest sites were analyzed separately. Data were checked for normal distribution of the residues by the Shapiro-Wilk test and homogeneity of variances by the Bartlett test. Analysis of variance was performed and the treatment means were compared by the Duncan's test $(P<0.05)$.

Simple correlation coefficients were calculated (Pearson's correlation) among the mean values of the physical and physiological parameters of seeds and seedlings with those obtained by the reflectance of fruits at $5 \%$ probability by the t-test $(P<0.05)$. In addition, the harvest sites were gathered and the lower and higher control limits were determined to monitor the average of the color spectra in the maturity stage in which ripe seeds were obtained.

\section{Results and Discussion}

The seeds from green fruits coming from the municipalities of Santa Helena and Guaíra were short in length and diameter. For seeds from the region of Entre Rios do Oeste, the smallest diameter was also evident in green fruits, while the length was not different until the stage at which the fruits were yellow. The maximum length values were obtained for seeds extracted from fruits with orange coloring, coinciding with the maximum accumulation of dry matter, also for the different harvesting sites (Table 2).

The seeds diameter fluctuated with the advance of the fruits ripening stages, making it impossible to forecast a default behavior for seeds harvested in different regions. At site 1 , the largest diameter was obtained soon after the fruits reached the green-yellow color, while at sites 2 and 3 it was obtained in orange and red fruits, respectively (Table 2). According to Fenner and Thompson (2005), the seed size is a plastic characteristic that can be altered within populations, individual plants, inflorescences and even in fruits due to environmental conditions in ripening, genetic factors, pollination rate, availability of nutrients, water, light and position of the fruit on the plant.

Table 2. Length (LENGTH), diameter (DIAM), dry matter mass (DMM) and moisture content (MC) of seeds of $A$. edulis harvested in different ripening stages of the fruits in the municipalities of Santa Helena (1), Entre Rios do Oeste (2) and Guaíra (3), Paraná, Brazil, 2014(1).

\begin{tabular}{|c|c|c|c|c|c|}
\hline \multirow{2}{*}{ Harvesting site } & \multirow{2}{*}{ Ripening stage of the fruits } & LENGTH & DIAM & \multirow{2}{*}{$\begin{array}{c}\text { DMM } \\
--- \text { mg --- }\end{array}$} & \multirow{2}{*}{$\begin{array}{c}\mathrm{MC} \\
---\% \text {--- }\end{array}$} \\
\hline & & \multicolumn{2}{|c|}{----------- mm ---------- } & & \\
\hline \multirow{5}{*}{1} & Green & $4.70 \mathrm{c}$ & $4.18 \mathrm{~b}$ & $9.21 \mathrm{~d}$ & $56.2 \mathrm{a}$ \\
\hline & Green-yellow & $4.95 \mathrm{~b}$ & $4.45 \mathrm{a}$ & $15.23 \mathrm{c}$ & $49.6 \mathrm{~b}$ \\
\hline & Yellow & $5.00 \mathrm{~b}$ & $4.44 \mathrm{a}$ & $18.63 \mathrm{~b}$ & $47.3 \mathrm{~b}$ \\
\hline & Orange & $5.08 \mathrm{ab}$ & $4.56 \mathrm{a}$ & $27.11 \mathrm{a}$ & $36.6 \mathrm{c}$ \\
\hline & Red & $5.18 \mathrm{a}$ & $4.48 \mathrm{a}$ & $27.38 \mathrm{a}$ & $34.1 \mathrm{c}$ \\
\hline $\mathrm{CV}(\%)$ & & 1.8 & 2.3 & 7.5 & 4.2 \\
\hline \multirow{5}{*}{2} & Green & $4.43 \mathrm{~b}$ & $4.06 \mathrm{~d}$ & $9.98 \mathrm{c}$ & $59.8 \mathrm{a}$ \\
\hline & Green-yellow & $4.48 \mathrm{~b}$ & $4.24 \mathrm{c}$ & $13.74 \mathrm{~b}$ & $49.2 \mathrm{~b}$ \\
\hline & Yellow & $4.55 \mathrm{~b}$ & $4.12 \mathrm{~d}$ & $14.50 \mathrm{~b}$ & $47.1 \mathrm{~b}$ \\
\hline & Orange & $5.02 \mathrm{a}$ & $4.42 \mathrm{~b}$ & $18.66 \mathrm{a}$ & $37.9 \mathrm{c}$ \\
\hline & Red & $4.98 \mathrm{a}$ & $4.91 \mathrm{a}$ & $19.14 \mathrm{a}$ & $36.0 \mathrm{c}$ \\
\hline CV (\%) & & 2.3 & 1.4 & 7.8 & 3.3 \\
\hline \multirow{5}{*}{3} & Green & $4.33 \mathrm{~d}$ & $3.93 \mathrm{c}$ & $9.96 \mathrm{c}$ & $61.4 \mathrm{a}$ \\
\hline & Green-yellow & $4.80 \mathrm{c}$ & $4.15 \mathrm{~b}$ & $14.16 \mathrm{~b}$ & $56.9 \mathrm{~b}$ \\
\hline & Yellow & $5.05 \mathrm{~b}$ & $4.37 \mathrm{a}$ & $14.42 \mathrm{~b}$ & $52.0 \mathrm{c}$ \\
\hline & Orange & $5.18 \mathrm{ab}$ & $4.28 \mathrm{ab}$ & $17.38 \mathrm{a}$ & $44.8 \mathrm{~d}$ \\
\hline & Red & $5.25 \mathrm{a}$ & $4.21 \mathrm{~b}$ & $18.15 \mathrm{a}$ & $40.7 \mathrm{e}$ \\
\hline CV (\%) & & 2.3 & 2.1 & 4.5 & 2.9 \\
\hline
\end{tabular}

(1) Means followed by equal letters in the column do not differ statistically among themselves by the Duncan's test at $5 \%$ error probability.

The accumulation of dry matter in the seeds increased until the stage where the fruits were orange (Table 2), with no significant increases in relation to the seeds extracted from red fruits, indicating that the seeds physiological 
maturity is subsequently reached at the maximum dry matter accumulation, because the seeds physiological potential is noticeably higher in seeds extracted from red fruits (Table 3 ). Therefore, for seeds of A. edulis, associating the maximum dry matter accumulation to the time of harvest can result in seed harvest with lower physiological potential.

The water content in the seeds decreased with the advance in fruit ripening (Table 2). However, it is observed that seed water content from sites 1 and 2 stabilized at the stage when the fruits reached the orange color, unlike at site 3 , where no stabilization occurred. Although there was a gradual reduction of the water content, the amount found in red fruits seeds (average 37\%) can be considered high in comparison to that observed by Wielewicki et al. (2006) and José et al. (2007) who obtained seeds with 28 and $26 \%$ moisture, respectively.

It is known that the seed and the atmosphere are two systems which are in continuous exchange of moisture at the end of ripening (Marcos-Filho, 2015). That said, it is noted that despite the start of the seed dispersion occurring in the rainy season (September) (Figure 1a), the atmosphere was drier at sites 1 and
2 , since the vapor pressure deficit at site 1 was on average $42 \%$ higher compared to site 3 , with a difference of only $3 \%$ compared to site 2 (Figure 1d). The smallest amount of water vapor in the atmosphere has an increased desiccant capacity, which justifies a more rapid loss of moisture from seeds collected at sites 1 and 2 (Table 2). The influence of climate and water conditions on the seeds moisture content was also demonstrated by Martins et al. (2009) in seeds of Euterpe edulis Mart., thus supporting the hypothesis that the loss of water during ripening is modulated by the ambient weather conditions.

There was a gradual increase in germination during ripening with maximum germination values for seeds extracted from red fruits in all harvest sites. On the other hand, low germination was found in fruits harvested at early stages of ripening when the seeds also had the lowest accumulation of dry matter (Table 3), which agrees with what was observed in seeds of Eugenia pyriformis Cambess and Campomanesia xanthocarpa O. Berg., wherein the lower germination speed was derived from seeds with lower dry matter extracted from green fruits (Herzog et al., 2012; Oro et al., 2012).

Table 3. Percentage of germination (G), germination speed index (GSI), mean germination time (MGT), seedlings dry matter (SDM) and seedlings length (SL) of $A$. edulis harvested in different ripening stages of the fruits in the municipalities of Santa Helena (1), Entre Rios do Oeste (2) and Guaíra (3), Paraná, Brazil, 2014(1).

\begin{tabular}{|c|c|c|c|c|c|c|}
\hline \multirow{2}{*}{ Harvesting site } & \multirow{2}{*}{ Ripening stage of the fruits } & G & GSI & MGT & SDM & SL \\
\hline & & $\%$ & & days & $\mathrm{mg}$ & $\mathrm{cm}$ \\
\hline \multirow{5}{*}{1} & Green & $4 \mathrm{e}$ & $0.002 \mathrm{e}$ & $37.0 \mathrm{a}$ & $7.19 \mathrm{c}$ & $5.0 \mathrm{c}$ \\
\hline & Green-yellow & $18 \mathrm{~d}$ & $0.145 \mathrm{~d}$ & $32.8 \mathrm{~b}$ & $8.17 \mathrm{c}$ & $7.3 \mathrm{~b}$ \\
\hline & Yellow & $34 \mathrm{c}$ & $0.313 \mathrm{c}$ & $28.4 \mathrm{c}$ & $13.56 \mathrm{~b}$ & $10.0 \mathrm{a}$ \\
\hline & Orange & $50 \mathrm{~b}$ & $0.521 \mathrm{~b}$ & $25.0 \mathrm{~d}$ & $15.75 \mathrm{ab}$ & $10.7 \mathrm{a}$ \\
\hline & Red & $65 \mathrm{a}$ & $0.753 \mathrm{a}$ & $21.2 \mathrm{e}$ & $16.70 \mathrm{a}$ & $11.6 \mathrm{a}$ \\
\hline \multirow[t]{3}{*}{ CV $(\%)$} & & 10.8 & 7.3 & 5.2 & 15.6 & 13.4 \\
\hline & Green & $3 \mathrm{e}$ & $0.020 \mathrm{e}$ & $34.5 \mathrm{a}$ & $7.3 \mathrm{c}$ & $7.3 \mathrm{c}$ \\
\hline & Green-yellow & $24 \mathrm{~d}$ & $0.201 \mathrm{~d}$ & $31.6 \mathrm{~b}$ & $8.0 \mathrm{c}$ & $7.1 \mathrm{c}$ \\
\hline \multirow[t]{3}{*}{2} & Yellow & $34 \mathrm{c}$ & $0.319 \mathrm{c}$ & $27.9 \mathrm{c}$ & $9.6 \mathrm{~b}$ & $8.9 \mathrm{ab}$ \\
\hline & Orange & $61 \mathrm{~b}$ & $0.575 \mathrm{~b}$ & $27.8 \mathrm{c}$ & $9.4 \mathrm{~b}$ & $8.1 \mathrm{bc}$ \\
\hline & Red & $85 \mathrm{a}$ & $0.880 \mathrm{a}$ & $24.8 \mathrm{~d}$ & $11.3 \mathrm{a}$ & $9.9 \mathrm{a}$ \\
\hline \multirow[t]{3}{*}{ CV (\%) } & & 12.1 & 9.9 & 4.4 & 6.8 & 8.6 \\
\hline & Green & $13 \mathrm{~d}$ & $0.025 \mathrm{~d}$ & $39.73 \mathrm{a}$ & $12.3 \mathrm{~d}$ & $6.7 \mathrm{~d}$ \\
\hline & Green-yellow & $18 \mathrm{~d}$ & $0.026 \mathrm{c}$ & $38.26 \mathrm{~b}$ & $12.4 \mathrm{~d}$ & $7.4 \mathrm{~d}$ \\
\hline \multirow[t]{3}{*}{3} & Yellow & $25 \mathrm{c}$ & $0.026 \mathrm{c}$ & $38.30 \mathrm{~b}$ & $14.3 \mathrm{c}$ & $9.2 \mathrm{c}$ \\
\hline & Orange & $60 \mathrm{~b}$ & $0.032 \mathrm{~b}$ & $31.72 \mathrm{c}$ & $16.8 \mathrm{~b}$ & $10.9 \mathrm{~b}$ \\
\hline & Red & $68 \mathrm{a}$ & $0.037 \mathrm{a}$ & $27.63 \mathrm{~d}$ & $19.7 \mathrm{a}$ & $12.6 \mathrm{a}$ \\
\hline CV (\%) & & 11.2 & 1.8 & 2.4 & 6.5 & 6.1 \\
\hline
\end{tabular}

(1) Means followed by equal letters in the column do not differ statistically by the Duncan's test at $5 \%$ error probability.

Studies on ripening in Sapindaceae seeds are scarce. Martins et al. (2011), studying the ripening of Sapindus saponaria Mart, have noted low germination in seeds extracted from green fruits, attributing this behavior to an incomplete seed formation. Therefore, it is believed that the low germination of A. edulis seeds obtained from green fruits is the result of 
seeds not being fully developed. It is observed that the amount of reserves deposited at this stage was the lowest compared to later stages and thus may have represented a limiting factor for the development of seedlings (Table 3).

The speed index, such as for germination, has also increased over the fruit ripening, being higher in seeds extracted from red fruits, while the average time, in contrast, has decreased (Table 3), indicating that seeds from red fruits are the most vigorous. According to Calil et al. (2005), these results are relevant for planning seedlings production in nurseries, since in seeds with physiological ripening germination occurs in less time, reducing the time to produce seedlings.

In addition, seeds derived from red fruits at sites 2 and 3 have also produced seedlings with greater dry matter mass and length. At site 1, seedlings with greater accumulation of dry matter were obtained from the stage when the fruits were orange color and with greater length from yellow fruits (Table 3). Lima et al. (2012) have found that the maximum dry matter content and length of seedlings of Poincianella pyramidalis [(Tul.) L. P. Queiroz] coincided with the time when the seeds had a higher germination speed index. Thus, it is suggested that the highest seed germination speed of $A$. edulis at this stage may have favored the rapid establishment of seedlings, thus promoting the highest growth rates in relation to the other stages.

Considering the set of physical and physiological attributes evaluated in seeds of A. edulis, it was found that physiological maturity was reached in seeds from red fruits, regardless of the harvest region, where they already had the maximum dry matter accumulation and the highest physiological potential, with a lower moisture content. In this case, the fruits showed signs of natural abscission due to peduncle weakening, characterizing the final stage before dispersion. However, the color properties evidenced with the use of the "Munsell color charts for plant tissues" have revealed that there is a variation in color of the fruits among the harvest sites, especially in the stage where the seeds are ripe, which may raise doubts at harvest if the visual parameter is used.

The variation was more pronounced in fruits harvested at site 1 , which exhibited a more intense red coloring (Table 1). According to Jimenez-Garcia et al. (2013), fruit color changing during ripening is associated with degradation of chlorophyll and anthocyanin biosynthesis, which are a class of flavonoids synthesized from the phenylpropanoid pathway responsible for giving reddish and bluish colors and purple shades in fruits.

The phenylpropanoid pathway responds to various environmental stimuli, such as temperature, photoperiod (Uleberg et al., 2012), soil fertility (Lillo et al., 2008) and in particular light, which is the main factor that contributes to the accumulation of flavonoids in fruits (Zoratti et al., 2014). The radiation incidence at sites 2 and 3 was an average of 55 to $16 \%$ lower than at site 1 (Figure 1a). Therefore, the higher incidence of radiation verified at site 1 in relation to other sites may have contributed to the increase in anthocyanin concentration in the epicarp, justifying the more intense color of these fruits in the last stage of ripening. Additionally, the lower radiation observed at site 2 justifies the lighter color of the fruits in the last stage of ripening, as evidenced by the spectrum values of red and green of the color analyzer (Table 4).

Table 4. Mean values of reflectance of the fruits of $A$. edulis harvested in different ripening stages under the color spectrum red (R), green (G) and blue (B) in the municipalities of Santa Helena (1), Entre Rios do Oeste (2) and Guaíra (3), Paraná, Brazil, 2014(1).

\begin{tabular}{|c|c|c|c|c|}
\hline \multirow{2}{*}{ Harvesting site } & \multirow{2}{*}{ Ripening stage of the fruits } & $\mathrm{R}$ & $\mathrm{G}$ & $\mathrm{B}$ \\
\hline & & \multicolumn{3}{|c|}{----------------------------- nm ---------------------------- } \\
\hline \multirow{5}{*}{1} & Green & $167.75 \mathrm{c}$ & $137.15 \mathrm{~b}$ & $53.05 \mathrm{~b}$ \\
\hline & Green-yellow & $263.10 \mathrm{~b}$ & $189.20 \mathrm{a}$ & $70.95 \mathrm{a}$ \\
\hline & Yellow & $306.65 \mathrm{a}$ & $187.95 \mathrm{a}$ & $65.65 \mathrm{a}$ \\
\hline & Orange & $164.35 \mathrm{c}$ & $59.30 \mathrm{c}$ & $33.40 \mathrm{c}$ \\
\hline & Red & $98.25 \mathrm{~d}$ & $33.30 \mathrm{~d}$ & $28.65 \mathrm{c}$ \\
\hline \multirow[t]{2}{*}{ CV $(\%)$} & & 10.4 & 11.0 & 10.9 \\
\hline & Verde & $111.53 \mathrm{c}$ & $97.93 \mathrm{~b}$ & $43.80 \mathrm{~b}$ \\
\hline \multirow{4}{*}{2} & Green-yellow & $213.75 \mathrm{~b}$ & $169.25 \mathrm{a}$ & $69.55 \mathrm{a}$ \\
\hline & Yellow & $305.95 \mathrm{a}$ & $173.15 \mathrm{a}$ & $72.70 \mathrm{a}$ \\
\hline & Orange & $229.15 b$ & $91.85 \mathrm{~b}$ & $41.70 \mathrm{~b}$ \\
\hline & Red & $137.80 \mathrm{c}$ & $48.00 \mathrm{c}$ & $33.30 \mathrm{~b}$ \\
\hline \multirow[t]{2}{*}{ CV (\%) } & & 13.0 & 12.7 & 13.6 \\
\hline & Green & $242.60 \mathrm{~d}$ & $186.40 \mathrm{~b}$ & $73.10 \mathrm{~b}$ \\
\hline \multirow{4}{*}{3} & Green-yellow & $346.55 \mathrm{~b}$ & $238.35 \mathrm{a}$ & $92.30 \mathrm{a}$ \\
\hline & Yellow & $382.95 \mathrm{a}$ & $230.30 \mathrm{a}$ & $84.50 \mathrm{a}$ \\
\hline & Orange & $283.20 \mathrm{c}$ & $109.70 \mathrm{c}$ & $48.00 \mathrm{c}$ \\
\hline & Red & $111.05 \mathrm{e}$ & $36.05 \mathrm{~d}$ & $28.70 \mathrm{~d}$ \\
\hline CV (\%) & & 5.8 & 7.3 & 9.0 \\
\hline
\end{tabular}

(1) Means followed by equal letters in the column do not differ statistically by the Duncan's test at $5 \%$ error probability. 
It is noted by the digital colorimetry that the reflectance values in the green spectrum allowed the best differentiation of the fruit ripening stages compared with reflectance values in red and blue spectra. This is because the values obtained in the red spectrum did not allow to segregate green fruits from the red ones for site 2, and the same happened for the spectrum of blue, which did not differentiate orange fruits from red ones at sites 1 and 2 (Table 4).

The colorimeter measures reflectance, i.e., the ability of an object to reflect the radiant energy by assigning numerical values to this variable (Steffen, 2016). It is noted that the average values found in the stage in which the seeds have reached maturity under the spectrum of green are different among sites, making it impossible to recommend a single average value for the harvest of ripe seeds. Thus, through the control chart it was possible to establish control limits for the different color spectra of the digital colorimeter in fruits of $A$. edulis harvested with red color (Figure 2). For the red spectrum (Figure 2a) the range was from 96.1 to $139.80 \mathrm{~nm}$; for the green one (Figure 2b), from 28.0 to $49.2 \mathrm{~nm}$; and for the blue one (Figure 2c), from 23.7 to $36.8 \mathrm{~nm}$. However, for the harvest of A. edulis seeds with physiological maturity, the use of reflectance values between 28.0 and $49.2 \mathrm{~nm}$ of the green color spectrum for western Paraná is recommended. The use of other color spectra can have a mixture of ripening stages with the harvest of unripe seeds of lower quality.

In addition, there was no significant correlation between the physical and physiological parameters quantified in seeds with reflectance values in red color, which maintains that these parameters are not directly associated with the fruit color (Table 5). A significant correlation between length and diameter of the seed and seedling dry matter with reflectance values in the green and blue colors was not shown either, suggesting that the plasticity of the morphometric characteristics of the seeds is shaped by the environment and not by the fruit development stage.

Other parameters evaluated significantly related with fruit color, whereas for the moisture content and mean germination time the correlation was positive and, for the dry matter mass, normal seedlings, speed germination speed and seedlings length the correlation was negative. Therefore, these characteristics are probably related to the stage of development of the fruits (Table 5).

It is noteworthy that the correlation coefficients were higher in the green color compared to blue (Table 5), showing that the green color spectrum provides greater accuracy at the time of harvest, corroborating the results shown on the control chart (Figure 2). Therefore, the interval between 28.0 and 49.2 $\mathrm{nm}$ of the green color spectrum of a 10-bit digital colorimeter
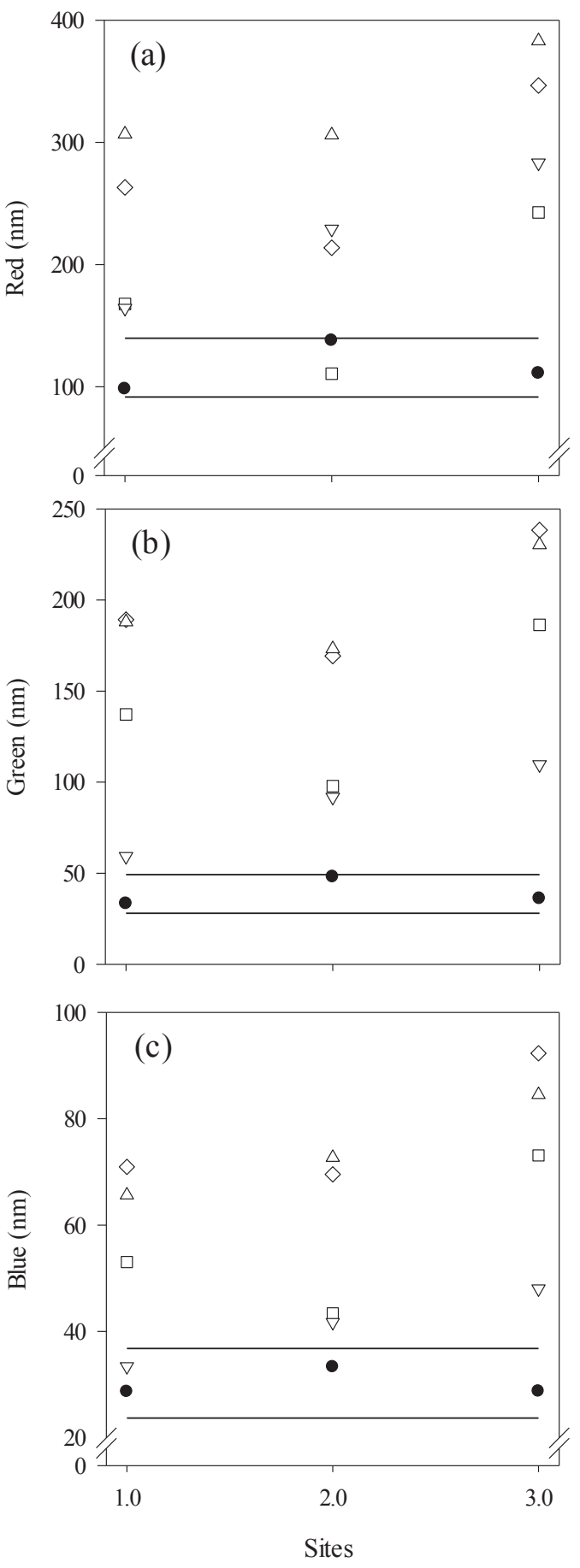

Figure 2. X-bar control chart for monitoring the average of the color spectrum of red (a), green (b) and blue (c) in the red stage of the fruits of $A$. edulis due to the sites and ripening stages. Santa Helena (site 1), Entre Rios do Oeste (site 2) and Guaíra (site 3) ( $\square$ ) green fruit; $(\diamond)$ green-yellow fruit; $(\Delta)$ yellow fruit; $(\nabla)$ orange-colored fruit; $(\bullet)$ red fruit. 
can be safely used to quantify the color of the fruit, being a less subjective alternative than the visual analysis of color, in addition to being reproducible and providing automation, allowing to obtain ripe seeds of $A$. edulis.

Table 5. Simple correlation coefficient among the parameters quantified in the seeds with reflectance values in red, green and blue of the visible spectrum measured in the epicarp of the fruits of $A$. edulis at different ripening stages and harvesting sites.

\begin{tabular}{lccc}
\hline \multicolumn{1}{c}{ Parameters } & Red & Green & Blue \\
\hline Length & -0.06 & -0.43 & -0.45 \\
Diameter & -0.19 & -0.42 & -0.43 \\
Dry matter mass & -0.29 & $-0.58^{*}$ & $-0.56^{*}$ \\
Moisture content & 0.37 & $0.72^{* *}$ & $0.69^{* *}$ \\
Normal seedlings & -0.33 & $-0.71^{* *}$ & $-0.66^{* *}$ \\
Germination speed index & -0.38 & $-0.57^{*}$ & $-0.54^{*}$ \\
Mean germination time & 0.51 & $0.75^{* *}$ & $0.72^{* *}$ \\
Seedlings dry matter & -0.06 & -0.36 & -0.34 \\
Seedling length & -0.22 & $-0.57^{*}$ & $-0.54^{*}$ \\
\hline
\end{tabular}

**** Significant at 5 and $1 \%$ by the t-test. $(n=15)$.

\section{Conclusions}

Seeds of A. edulis with physiological maturity should be harvested from fruits with the epicarp color predominantly red, independent of the harvesting region.

Reflectance values between 28.0 and $49.2 \mathrm{~nm}$ of the green color spectrum of a 10-bit digital colorimeter can be used for seed harvest with physiological maturity in arrays located in the western region of Paraná.

\section{Acknowledgments}

The authors thank Coordination for the Improvement of Higher Education Personnel, Araucaria Foundation for Supporting Scientific and Technological Development of Paraná, and National Council for Scientific and Technological Development for granting the scholarship.

\section{References}

ABREU, D.C.A; KUNIYOSHI, Y.S.; NOGUEIRA, A.C.; MEDEIROS, A.C.S. Caracterização morfológica de frutos, sementes e germinação de Allophylus edulis (St.-Hil.) Radlk. (Sapindaceae). Revista Brasileira de Sementes, v.27, n.2, p.59-66, 2005. http://www.scielo.br/scielo. php?pid $=$ S0101-31222005000200009\&script $=$ sci_arttext
ACEVEDO-RODRÍGUEZ, P.; VAN WELZEN, P.C.; ADEMA, F.; VAN DER HAM, R.W.J.M. Sapindaceae. In: KUBITZKI, K. (Ed). The Families and Genera of Vascular Plants - Flowering Plants. Eudicots: Sapindales, Cucurbitales, Myrtaceae. Berlin: Springer, 2011, p.357-407.

BRASIL. Ministério da Agricultura, Pecuária e Abastecimento. Regras para análise de sementes. Ministério da Agricultura, Pecuária e Abastecimento. Secretaria de Defesa Agropecuária. Brasília: MAPA/ACS, 2009, 395p. http:// www.agricultura.gov.br/arq_editor/file/2946_regras_analise_sementes.pdf

CALIL, A.C.; LEONHARDT, C.; BUSNELlO, A.C.; BUENO, O.L. Época de coleta de sementes de Maytenus dasyclada Mart. - Celastraceae no Jardim Botânico de Porto Alegre, RS, Brasil. IHERINGIA, Série Botânica, v.60, n.1, p.11-16, 2005. http://www.fzb.rs.gov.br/ upload/20140328135946ih60p11_16.pdf

CORDEIRO, J.; RODRIGUES, W.A. Caracterização fitossociológica de um remanescente de floresta ombrófila mista em Guarapuava, PR. Revista Árvore, v.31, n.3, p.545-554, 2007. http://www.scielo.br/scielo.php?script=sci arttext\&pid=S0100-67622007000300020

CORDEIRO, M.W.S.; CAVALLIERI, A.L.F.; FERRI, P.H.; NAVES, M.M.V. Características físicas, composição químico-nutricional e dos óleos essenciais da polpa de Caryocar brasiliense nativo do estado de Mato Grosso. Revista Brasileira de Fruticultura, v.35, n.4, p.1127-1139, 2013. http://www.scielo. br/scielo.php?script=sci_arttext\&pid=S0100-29452013000400024

DRANSKI, J.A.L.; PINTO JÚNIOR, A.S.; STEINER, F.; ZOZ, T.; MALAVASI, U.C.; MALAVASI, M.M.; GUIMARÃES, V.F. Physiological maturity of seeds and colorimetry of fruits of Jatropha curcas L. Revista Brasileira de Sementes, v.32, n.4, p.158-165, 2010. http://www.scielo.br/ scielo.php?script=sci_arttext\&pid=S0101-31222010000400018

DUARTE, A.R.; SANTOS, S.C.; SERAPHIN, J.C.; FERRI, P.H. Influence of spatial, edaphic and genetic factors on phenols and essential oils of Myrciaria cauliflora fruits. Journal of the Brazilian Chemical Society, v.23, n.4, p.737-746, 2012. http://www.scielo.br/scielo.php?pid=S0103$50532012000400020 \&$ script $=$ sci_abstract

FENNER, M.; THOMPSON, K. The ecology of seeds. Cambridge: Cambridge University Press, 2005. 250p.

GRIS, D.; TEMPONI, L.G.; MARCON, T.R. Native species indicated for degraded area recovery in western Paraná, Brazil. Revista Árvore, v.36, n.1, p.113-125, 2012. http://www.scielo.br/scielo.php?script=sci arttext\&pid=S0100-67622012000100013

HACK, C.; LONGHI, S.J.; BOLIGON, A.A.; MURARI, A.B.; PAULESKI, D.T. Análise fitossociológica de um fragmento de floresta estacional decidual no município de Jaguari, RS. Ciência Rural, v.35, n.5, p.1083-1091, 2005. http://www.scielo.br/scielo.php?script=sci arttext\&pid=S0103-84782005000500015

HERZOG, N.F.M.; MALAVASI, M.M.; MALAVASI, U.C. Morfometria dos frutos e germinação de sementes de Campomanesia xanthocarpa O. Berg. Semina: Ciências Agrárias, v.33, n.4, p.1359-1366, 2012. http://www.uel.br/ revistas/uel/index.php/semagrarias/article/view/7429

ISTA - International Seed Testing Association. Handbook of vigor tests methods. 3. ed. Zürich: ISTA, 1995. 117 p.

JIMENEZ-GARCIA, S.N.; GUEVARA-GONZALEZA, R.G.; MIRANDALOPEZB, R.; FEREGRINO-PEREZC, A.A.; TORRES-PACHECOA, I.; VAZQUEZ-CRUZ, M.A. Functional properties and quality characteristics of bioactive compounds in berries: biochemistry, biotechnology, and genomics. Food Research International, v.54, n.1, p.1195-1207, 2013. http://www. sciencedirect.com/science/article/pii/S0963996912004735 
JOSÉ, A.C.; SILVA, E.A.; DAVIDE, A.C. Classificação fisiológica de sementes de cinco espécies arbóreas de mata ciliar quanto a tolerância à dessecação e ao armazenamento. Revista Brasileira de Sementes, v.29, n.2, p.171-178, 2007. http://www.scielo.br/scielo.php?pid=S0101$31222007000200023 \&$ script $=$ sci_arttext

LABORIAU, L.G. A germinação das sementes. Washington: Organização dos Estados Americanos, 1983. 174 p.

LANDSBERG, J.J.; SANDS, P. Physiological ecology of forest production: principles, processes and models. New York: Academic Press, 2011. 352 p.

LILLO, C.; LEA, U.S.; RUOFF, P. Nutrient depletion as a key factor for manipulating gene expression and product formation in different branches of the flavonoid pathway. Plant, Cell \& Environment, v.31, n.5, p.587-601, 2008. http://onlinelibrary.wiley.com/doi/10.1111/j.1365-3040.2007.01748.x/abstract

LIMA, C.R.; BRUNO, R.L.A.; SILVA, K.R.G; PACHECO, M.V.; ALVES, E.U.; ANDRADE, A.P. Physiological maturity of fruits and seeds of Poincianella pyramidalis (Tul.) L.P. Queiroz. Revista Brasileira de Sementes, v.34, n.2, p.231-240, 2012. http://www.scielo.br/scielo.php?script=sci arttext\&pid=S0101-31222012000200007

LIMA, V.L.A.G.; MÉLO, E.A.; GUERRA, N.B. Correlação entre o teor de antocianinas e caracterização cromática de polpas de diferentes genótipos de aceloreira. Brasilian Journal of Food, v.10, n.1, p.51-55, 2007. http://www. ital.sp.gov.br/bj/artigos/bjft/2007/p06272.pdf

LOPES, I.S.; NÓBREGA, A.M.F.; MATOS, V.P. Maturação e colheita da semente de Amburana cearensis (Allem.) A.C. Smith. Ciência Florestal, v.24, n.3, p.565-572, 2014. http://cascavel.ufsm.br/revistas/ojs-2.2.2/index. $\mathrm{php} /$ cienciaflorestal/article/view/4190

MAGUIRE, J.D. Speed of germination aid in selection and evaluation for seedling emergence and vigor. Crop Science, v.2, n.2, p.176-177, 1962. https://dl.sciencesocieties.org/publications/cs/abstracts/2/2/CS0020020176

MARCOS-FILHO, J. Fisiologia de sementes de plantas cultivadas. 2. ed. Londrina: ABRATES, 2015. $560 \mathrm{p}$.

MARTINS, C.C.; BOVI, M.L.A.; NAKAGAWA, J.; MACHADO, C.G. Secagem e armazenamento de sementes de juçara. Revista Árvore, v.33, n.4, 635-642, 2009. http://www.scielo.br/scielo.php?script=sci arttext\&pid=S0100-67622009000400006

MARTINS, C.C.; ZUCARELI, C.; COIMBRA, R.A. Procedimentos de colheita dos frutos na qualidade fisiológica de sementes de Sapindus saponaria Mart. Semina: Ciências Agrárias, v.32, suplemento 1, p.1825-1830, 2011. http://www.uel.br/revistas/uel/index.php/semagrarias/article/view/5656

MUNSELL, A.H. Munsell book of color. Baltimore: Macbeth Vivision of Kollmorgen, 1976. 23 p.

NAKAGAWA, J. Testes de vigor baseados no desempenho das plântulas. In: KRZYZANOWSKI, F.C.; VIEIRA, R.D.; FRANÇA-NETO, J.B. Vigor de sementes: conceitos e testes. Londrina: ABRATES, 1999. cap.2, p.1-24.
ORO, P.; SCHULZ, D.G.; VOLKWEIS, C.R.; BANDEIRA, K.B.; MALAVASI, U.C.; MALAVASI, M.M. Maturação fisiológica de sementes de Eugenia pyriformis Cambess e Eugenia involucrata DC. Biotemas, v.25, n.3, p.11-18, 2012. https://periodicos.ufsc.br/index.php/biotemas/article/ view/2175-7925.2012v25n3p11/22796

PIÑA-RODRIGUES, F.C.M.; AGUIAR, I.B. Maturação e dispersão de sementes. In: AGUIAR, I.B.; PIÑA-RODRIGUES, F.C.M.; FIGLIOLIA, M.B. Sementes florestais tropicais. Brasília: ABRATES, 1993. p. 215-274.

SAVVA,Y.; KOUBAA, A.; TREMBLAY, F.; BERGERON, Y. Effects of radial growth, tree age, climate, and seed origin on wood density of diverse jack pine populations. Trees - Structure and Function, v.24, n.1, p.53-65, 2010. http://link.springer.com/article/10.1007\%2Fs00468-009-0378-0

SIMEPAR. Sistema Meteorológico do Paraná. Dados meteorológicos de Marechal Cândido Rondon - ano 2014. Curitiba: Simepar, 2015. http://www. simepar.br/site2/faleconosco. Accessed on: Nov. 17 th, 2015.

SOMNER, G.V.; FERRUCCI, M.S.; ACEVEDO-RODRÍGUEZ, P.; PERDIZ, R.O.; COELHO, R.L.G.; MEDEIROS, H. Sapindaceae in Lista de Espécies da Flora do Brasil. Jardim Botânico do Rio de Janeiro. http:// floradobrasil.jbrj.gov.br/jabot/floradobrasil/FB216 Acesso em: 09 ago. 2015.

SRIMATHI, P.; MARIAPPAN N.; SUNDARAMOORTHY, L.; SUDHAKAR, K. Studies on floral phenology, fruit and seed maturation and harvest index based on fruit colour in Pongamia pinnata (L.) Pierre. African Journal of Plant Science, v.7, n.11, p.513-520, 2013. http://www.academicjournals.org/ articles/j_articles/AJPS

STEFFEN, C.A. Introdução ao sensoriamento remoto. http://www.inpe.br/ unidades/cep/atividadescep/educasere/apostila.htm Acesso em: 22 fev. 2016.

ULEBERG, E.; ROHLOFF, J.; JAAKOLA, L.; TROST, K.; JUNTTILA, O.; HAGGMAN, H.; MARTINUSSEN, I. Effects of temperature and photoperiod on yield and chemical composition of northern and southern clones of bilberry (Vaccinium myrtillus L.) Journal of Agricultural and Food Chemistry, v.60, n.42, p.10406-10414, 2012. http://pubs.acs.org/doi/ abs/10.1021/jf302924m

WIELEWICKI, A.P.; LEONHARDT, C.; SCHLINDWEIN, G.; MEDEIROS, A.C.S. Proposta de padrões de germinação e teor de água para sementes de algumas espécies florestais presentes na Região Sul do Brasil. Revista Brasileira de Sementes, v.28, n.3, p.191-197, 2006. http://www.scielo.br/ scielo.php?pid=S0101-31222006000300027\&script=sci_abstract\&tlng=pt

ZORATTI, L.; KARPPINEN, K.; LUENGO ESCOBAR, A.; HÄGGMAN, H.; JAAKOLA, L. Light-controlled flavonoid biosynthesis in fruits. Frontiers in Plant Science, v.5, n.535, p.1-16, 2014. http://www.ncbi.nlm.nih.gov/ pmc/articles/PMC4191440/ 